\title{
Pacienta autonomijas un integritātes aizsardzība tiesību aktos
}

\author{
Dr. iur. Aldis Lieljuksis \\ ORCID: 0000-0003-2610-6690 \\ Rìgas Stradiña universitāte, Juridiskā fakultāte, Latvija \\ Aldis.Lieljuksis@rsu.lv
}

\section{Kopsavilkums}

Vairākās Eiropas valstīs - Polijā, Portugālē un Lihtenšteinā - paredzēta kriminālatbildība ne tikai par pacientam nodarìtu kaitējumu veselības aprūpē, bet arī tad, ja ārstniecība veikta bez pacienta piekrišanas situācijās, kad tā bija nepieciešama, jo tādējādi ir prettiesiski aizskartas cilvēka pamattiesības. Pētijums veikts, lai noskaidrotu, kādās Latvijas Republikas Satversmes VIII nodal̦as tiesību normās tiek garantēta personas autonomija un integritāte kā cilvēka pamattiesību neatṇemama vērtība, kā arī ielasāma pacienta informētā piekrišana kā pacienta galvenais līdzeklis šo aizsargājamo interešu nodrošināšanā.

Atslēgvārdi: Satversme, Krimināllikums, Satversmes tiesa, informētā piekrišana.

\section{levads}

Pasaules Veselības organizācijas Konstitūcijā veselība definēta ne tikai kā slimības vai nespējas trūkums, bet arī kā pilnīga fiziska, garīga un sociāla labklājība [4]. Katrs vēlas dzīvot šādā stāvoklī, taču nav garantijas, ka neslimos, un nonāk pacienta stāvoklī vai arī, lai neslimotu, savlaicīgi vēršas pie ārstniecības personas, lai saṇemtu profesionālu palīdzību.

Pacienta tiesības tiek iedalītas sociālajās tiesībās, kas saistītas ar pacienta kā sabiedrības locekḷa tiesībām un valsts pienākumu pret saviem iedzīvotājiem, nodrošinot pakalpojumu pieejamību, un individuālajās tiesībās, pie personas tiesībām iedalot tās tiesības uz ārstniecību, tiesības uz informāciju, informētu piekrišanu, konfidencialitāti un privātuma aizsardzību [27]. Atbilstoši Pacientu tiesību likuma 6. panta pirmajai daḷai ārstniecība ir piel̦aujama, ja pacients devis tai informēto piekrišanu. Šajā pētijumā tika noskaidrots, 
kā ielasāmas pacienta individuālās tiesības uz informētu piekrišanu ārstniecībā Latvijas Republikas Satversmes (turpmāk - Satversmes) VIII nodaḷas "Cilvēka pamattiesības" un citu tiesību nozaru normatīvo aktu normās, kā arī tas, vai šo tiesību aizsardzība ir nodrošināta pienācīgā līmenī.

Temats mūsdienās ir aktuāls, jo atsevišḳi ārsti un arī juristi pauž idejas, ka vajadzētu izslēgt Krimināllikuma 138. pantu un par ārstniecības personas nolaidīgu rīcību paredzēt tikai disciplināratbildību.

Jāuzsver, ka esošajā Krimināllikuma normā paredzēta kriminālatbildība par pacientam nodarīto kaitējumu veselībai vai dzīvībai, kad ārstniecības persona savus pienākums nav veikusi vai pildījusi nolaidīgi, ja iestājušās sekas, kas ir vismaz vidēji smagi miesas bojājumi. Ārstniecības personām paredzētajā literatūrā ievietoti raksti, kuru autori apgalvo, ka Krimināllikuma norma stigmatizē ārstniecības personas brīvi īstenot savas funkcijas un bailes no kriminālatbildības neveicina to, ka ārstniecības personas atklās savas kḷūdas un neveiksmes. Pretēji tam profesors V. Boka uzskata, ka kriminālatbildība paredzama, ja ārsts bijis bezatbildīgi nolaidīgs. Rakstā profesors sniedz arī savus uzskatus par bezatbildīgi nolaidīgas rīcības izpausmēm vai nodarījuma objektīvas puses izpausmēm, piemēram, nepareizu asins pārliešanu, nepareizu ekstremitātes amputēšanu, nepareizas zāḷ devas ievadīšanu, operācijas veikšanu vai zāḷu ievadīšanu nepareizam pacientam, l̦aunprātīgu pacienta tiesību uz piekrišanu ignorēšanu, elementāras higiēnas trūkumu, uzmanības nepievēršanu vienkāršām pazīmēm, ko būtu atradis jebkurš saprātīgs ārsts [31]. Savukārt ārsta P. Apiṇa rakstā, kurā izskatìts jautājums par ārstniecības personu kriminālatbildību un noliegta tās nepieciešamība, nepārprotami norādīts arī uz izmeklētāju, prokuroru un advokātu kompetences trūkumu, kas esot aizstāta ar revolucionāru pārliecību [29]. Uz ekspertu, kas izvērtē ārstniecības sekas, nepietiekamu kvalifikāciju, termina "medicīniska kḷūda" neesamību un nepieciešamību to definēt un atklāt tās saturu, kā arī nolaidīgas rīcības gadỉjumā ārstniecības personai piemērot disciplināratbildību norāda pētnieces A. Bankava un ārste E. Palčeja [30]. Savukārt medicīnas zinātṇu doktors un tiesību zinātṇu maǵistrs A. Lācis rakstā "Jatrogēnijas koncepcija" norāda, ka "medicīniskais pakalpojums, kurš veikts bez likumīga pamata, tāpat kā nelabvēlīgs notikums, kurš ir izraisījis kaitējumu veselībai šādu pakalpojumu sniegšanas rezultātā, nav uzskatāms par jatrogēniju un ir krimināli sodāms" [33].

Veselỉbas inspekcijas kā kontroles iestādes publiski pieejamā informācija liecina, ka arvien vairāk personu vēršas Ārstniecības riska fondā sakarā ar nodarīto kaitējumu, turklāt tiek norādītas arī jomas, par kurām saṇemts visvairāk sūdzību:

“2019. gadā Inspekcija izskatījusi lielāko iesniegumu skaitu Ārstniecības riska fonda (ĀRF) pastāvēšanas vēsturē - 254 iesniegumus. Kaitējuma esība pacienta veselībai vai dzīvībai noteikta 44 gadījumos, noteiktā kaitējuma apmērs svārstījies robežās no 1 \% līdz $100 \%$. 2019. gadā ĀRF iesniegumi, salīdzinot ar 2018. gadu, joprojām visbiežāk izskatīti četrās jomās: traumatologiijā - 51; kịurǵijā - 47; ginekologijā un dzemdniecībā - 32; zobārstniecībā - 27 iesniegumi." [41] 
Pētnieces K. Palkovas promocijas darbā "Nepilngadīgo pacientu un ārstniecības personu tiesisko attiecību problemātika ārstniecības procesā" konstatēts, ka tikai 43\% pediatru un specializēto bērnu ārstu zina, no cik gadiem pielaujama nepilngadīga pacienta ārstniecība, ja viña likumiskais pārstāvis par to ir informēts un devis savu piekrišanu. Savukārt tikai 31 \% citu ārstniecības personu zina šo aspektu [37]. Arī ārstniecības personu zināšanu līmenis par būtiskiem juridiskiem aspektiem ārstniecības procesā ne tuvu nav ideālam. Protams, ne visas problēmas ārstniecībā risināmas, izmantojot kardinālus krimināltiesiskus līdzekḷus, tomēr jautājums par sodu, pārkāpjot informētās piekrišanas nosacijjumus un lïdz ar to personas tiesības uz autonomiju un integritāti, ir aktuāls un izpētes vērts. Izpēte jāveic, lai konstatētu, vai Latvijas tiesību sistēmā ir atbilstoši nodrošinātas pacienta tiesības uz informēto piekrišanu un paredzēts pietiekams normatīvais regulējums pārkāpuma gadījumā, lai varētu teikt, ka šajā aspektā valsts ir pilnībā izpildījusi savu pozitīvo pienākumu pacienta integritātes un autonomijas aizsardzībai un ka jauna, speciāla Krimināllikuma norma nav nepieciešama.

Jautājumu par pārmērīgu ietekmi uz pacienta gribu kā prettiesisku rīcību, tās kritērijus un civiltiesiskās sekas aplūkojusi zinātniece L. Mazure, kas piedāvā papildināt "Pacientu tiesību likumu" ar regulējumu, kurā būtu noteikts, ka pacienta gribas izteikumu atzīst par spēkā neesošu, ja tas izteikts pārmērīgā kādas personas ietekmē [35]. Nepārprotami šis jautājums saistìts ne tikai ar civiltiesisko aspektu, bet arī ar Krimināllikuma 135. panta 4. dal̦as regulējumu par aborta neatḷautu izdarǐ̌anu pret grūtnieces gribu, kur subjekts var būt arī ārstniecības persona. Krimināllikuma 136. panta regulējumā paredzēta kriminālatbildība par grūtnieces piespiešanu izdarìt abortu, līdz ar to būtu jārisina jautājums par civiltiesiskās un krimināltiesiskās atbildības veidu nošḳiršanu.

Vairāku Eiropas valstu - Lihtenšteinas, Polijas un Portugāles - krimināltiesībās paredzēta norma par ārstniecību bez informētās piekrišanas, kas ir nodarījums pret personas pamattiesībām. Turklāt, piemēram, Lihtenšteinas Soda likuma 110. paragrāfā paredzēta atbildība par ārstniecību bez pacienta piekrišanas, kas ir nodarïjums pret personas brīiību, un noteiktu seku gadījumā, kas radušās aiz neuzmanības, 88. paragrāfā paredzēta atbildība ārstniecības personai par pacientam nodarītiem miesas bojājumiem, kas radījuši veselības traucējumus, kas turpinās ilgāk par 14 dienām [42].

Kādās tieši Satversmes normās paredzētas personas autonomijas un integritātes tiesības un vai par šo tiesību aizskārumu paredzama kriminālatbildība, aprakstīts nākamajā nodaḷā.

\section{Pacienta tiesību aizsardzība Satversmes normās}

Jautājumi par pacientu tiesību aizsardzību informētās piekrišanas kontekstā starptautiskajā tiesiskajā regulējumā ir plaši aplūkoti 2019. gadā izdotajā "Pacientu tiesību likuma komentārā", kā arī 2017. gadā publicētā pētījuma "Spīdzināšana, cietsirdība un pazemojums attieksmē un sodā" 4.3.2. apakšnodạ̣ā. Analizējot starptautiskos tiesību aktus izskatāmā jautājuma kontekstā, jākonstatē, ka jautājumā par atbildību tajos ir tikai 
vispārīgas frāzes, taču atbildības veidi nav konkretizēti. Arī iepriekšminētajos darbos nav pētīts pacientu informētās piekrišanas nodrošinājums, kas izriet no Satversmes VIII nodal̦ā ietvertajām normām. Pacientu tiesību likuma pirmā panta otrās dalıas 2. punktā definēts, ka informētā piekrišana ir pacienta piekrišana ārstniecībai, kuru viṇš dod mutvārdos, rakstveidā vai ar tādām darbībām, kas nepārprotami apliecina piekrišanu, turklāt dod to brīvi, pamatojoties uz ārstniecības personas savlaicīgi sniegto informāciju par ārstniecības mērkịi, risku, sekām un izmantojamām metodēm [5].

Satversme ir Latvijas valsts pamatlikums, kas stājās spēkā 1922. gada 7. novembrī. Savukārt cilvēktiesību katalogs, kas tika ieviests tās VIII nodạ̦ā "Cilvēka pamattiesības", kā likuma norma stājās spēkā 1998. gada 6. novembrī. Nodaḷā ietvertas normas no 89. līdz 116. pantam. Kā pamatoti norāda Satversmes normu pētnieki, tad Satversme nav tikai vēstures piemineklis; tas ir dzīvs instruments, kas ir interpretējams un piemērojams atbilstoši mūsdienu realitātēm un mūsdienu izpratnei par aizsargājamo pamattiesību standartu. [24] Atbilstoši Satversmes 85. pantam Latvijā pastāv Satversmes tiesa, kas saskaṇā ar likumā noteikto kompetenci izskata lietas par likuma atbilstību Satversmei, kā arī citas ar likumu tās kompetencē nodotās lietas [1].

Uzsverot Satversmes tiesas lomu, tās priekšsēdētāja I. Ziemele norāda:

“[..] aizstāvot konstitucionālās vērtības un ikvienas personas pamattiesības, konstitucio-
nālajai tiesai ir būtiska loma uz demokrātijas, tiesiskuma, cilvēktiesību un brīvās tirgus
ekonomikas pamatprincipiem balstītas valsts veidošanā un attīstī̌anā. Konstitucionālās
tiesas nolēmumi veido arī valsts prestižu, sekmē ekonomisko attīstību un ietekmē visus
konstitūcijā regulētos valstiskos procesus." [40]

Satversmes tiesas spriedums var ietekmēt risinājumu katra cilvēka pamattiesību aizskāruma gadījumā, jo, kā paredzēts Satversmes tiesas likuma $19^{2}$. panta pirmajā dạ̦ā, konstitucionālo sūdzību (pieteikumu) Satversmes tiesai var iesniegt ikviena persona, kura uzskata, ka tai Satversmē noteiktās pamattiesības aizskar tiesību norma, kas neatbilst augstāka juridiska spēka tiesību normai. Kā paredzēts Satversmes tiesas likuma 32. panta otrajā dậā, Satversmes tiesas spriedums un tajā sniegtā attiecīgās tiesību normas interpretācija ir obligāta visām valsts un pašvaldību institūcijām (arī tiesām) un amatpersonām, kā arī fiziskajām un juridiskajām personām [9]. Satversmes un Satversmes tiesas sprieduma saistošais raksturs ietverts citu tiesību procesuālajās normās. Tā, piemēram, Kriminālprocesa likuma 2. pantā paredzēts, ka kriminālprocesu nosaka Latvijas Republikas Satversme, starptautiskās tiesību normas un kriminālprocesa likums, savukārt, piemērojot Eiropas Savienības tiesību normu, ṇem vērā Eiropas Savienības Tiesas judikatūru, bet Latvijas Republikas tiesību normas piemērošanā ievēro Satversmes tiesas spriedumā sniegto attiecīgās normas interpretāciju [6]. Arī Administratīvā procesa likuma 17. panta piektajā dạ̦ā paredzēts - ja Satversmes tiesa attiecīgo tiesību normu ir interpretējusi spriedumā, iestāde un tiesa piemēro šo interpretāciju [7].

Turpinājumā aplūkotas Satversmes VIII nodaḷā ietvertās normas, starptautisko tiesību akti, Satversmes tiesas un citu tiesu nolēmumi saistībā ar informēto piekrišanu. 
Satversmes 89. pantā paredzēts, ka valsts atzīst un aizsargā cilvēka pamattiesības saskan̄ā ar šo Satversmi, likumiem un Latvijai saistošiem starptautiskajiem līgumiem. Satversme uzliek valsts institūcijām divējādus pienākumus: 1) negatīvu (pasīvu) pienākumu atturēties no darbībām, kas pārkāpj vai objektīvi riskē pārkāpt personas pamattiesības; 2) pozitīvu (aktīvu) pienākumu veikt noteiktas darbības, lai nodrošinātu privātpersonām iespēju brīvi un netraucēti baudìt savas pamattiesības. Ja valsts tomēr ir nepamatoti aizskārusi privātpersonas pamattiesības, tai ir jādod šai personai atbilstīgs un samērīgs atlīdzinājums saprātīgos termiṇos [24]. Valsts pozitīvais pienākums ir pieṇemt likumus, kas aizsargā personu, taču nav teikts, ka tām ir jābūt tieši krimināllikuma normām, kaut arī kriminālsoda mērḳis atbilstoši Krimināllikuma 35. pantam ir gan aizsargāt sabiedrības drošỉbu, gan atturēt citas personas no noziedzīgu nodarïjumu izdarī̌̌anas.

Arī starptautiskajos tiesību aktos nav konkretizēts atbildības veids, lietojot terminu "attiecīgu sankciju" [2]. Gandrīz pirms gadsimta, atbildot uz jautājumu, par ko likumdevējam jāsoda, profesors P. Mincs norādīja, ka "pamatā liekams ar tiesību aizsargāta labuma elements, kas aizpildìts ar reālu saturu un kas sakrīt ar laikmeta tiesisko apzinnu" [36]. Tas, ka tiesiskā apziṇa par pamattiesībām paplašinās un padziḷinās, ir acīmredzami. Piemēram, ir pieṇemts Administratīvā procesa likums, kura pamatmērḳis ir nodrošināt pamattiesību ievērošanu publiski tiesiskajās attiecībās starp valsti un privātpersonu. Izmaiñas pamattiesību aizsardzībā saskatāmas arī Krimināllikuma 48. panta 14. punkta redakcijā, kurā ir papildināts normas saturs. Taču Krimināllikumā nav normas, kas tieši paredzētu kriminālatbildību, aizsargājot ikvienu pacientu, ja notikusi ārstniecība bez piekrišanas gadījumā, kad tādai ir jābūt. Šeit, protams, paveras iespēja plašākai diskusijai un regulējumam arī par jautājumu, kad tieši informētai piekrišanai ir jābūt, un par pacienta gribas pārmērīgu ietekmēšanu.

Vērtējot Satversmes VIII nodaḷā ietverto normu aizskārumu krimināltiesiskā aspektā, Augstākās tiesas Senāts spriedumā ir norādījis, ka Satversmē garantēto tiesību aizskārums katrā ziṇā atzīstams par personas tiesību un interešu ievērojamu apdraudējumu likuma "Par Krimināllikuma spēkā stāšanās un piemērošanas kārtību" 23. panta izpratnē [22]. No sprieduma būtu secināms, ka ikviens Satversmē garantēto tiesību aizskārums būtu atzīstams par ievērojamu apdraudējumu un, ja apdraudējums ir ievērojams, par to jāparedz kriminālatbildība. Lìdz ar to būtu jānoskaidro, vai gadỉjumā, ja tiek pārkāpta kāda no Satversmē garantētajām tiesībām, ir piemērojama attiecīga Krimināllikuma norma. Ikviena pacienta integritāte un autonomija tiešā veidā ar Krimināllikuma normu nav aizsargāta, taču atsevišḳas normas ir saistāmas ar piekrišanu ārstniecībai pārkāpšanu, piemēram, aborta izdarī̌sana pret grūtnieces gribu, par ko paredzēta kriminālatbildība 136. panta ceturtajā dậa. Saskaṇā ar Krimināllikuma 138. panta normu par ārstniecības personas pienākumu nepildīšanu var uzskatīt situāciju, kad notikusi ārstniecība bez pacienta piekrišanas, taču kriminālatbildība iestājas, ja sekas ir vismaz vidēji smags miesas bojājums. Abas normas ietvertas Krimināllikuma XIII nodạ̦ā un nodarījuma objekts kā aizsargājamā interese ir personas veselība, nevis pamattiesības. 


\section{Citā Augstākās tiesas Senāta lēmumā precizēts:}

"[..] ne katrs Latvijas Republikas Satversmē garantēto tiesību aizskārums pats par sevi, bez aizskāruma izvērtējuma, atzīstams par būtisku kaitējumu likuma "Par Krimināllikuma spēkā stāšanās un piemērošanas kārtību” 23. panta izpratnē. Būtisks kaitējums nosakāms, pamatojoties uz tiesā pārbaudītiem pierādījumiem, izvērtējot interešu apdraudējuma veidu, saturu, intereses nesēja jeb personas, pret kuru vērsts apdraudējums, īpašîbas un attieksmi pret konkrēto interešu apdraudējumu" [19].

No iepriekšminētā secināms, ka ne katrs Satversmē garantēto tiesību aizskārums ir automātiski vērtējams kā ievērojams personas interešu aizskārums krimināltiesību izpratnē un tāpēc paredzama atbildība Krimināllikuma normā, savukārt, ja Satversmē garantētās tiesības aizskārums ir ietverts Krimināllikuma normā, tad tai jābūt saturiski noteiktai. Kriminālatbildība par Satversmē aizsargāto tiesību prettiesisku aizskārumu nav paredzēta tikai tad, ja iestājušās sekas un tās ir vismaz būtisks kaitējums krimināltiesību izpratnē. Tā, piemēram, Krimināllikuma 143. pantā paredzēta atbildība par personas mājokḷa neaizskaramības pārkāpšanu, taču būtisks kaitējums nav ietverts normas dispozīcijā, tāpat Krimināllikuma 144. pantā paredzēta atbildība par korespondences un pa elektronisko sakaru tīkliem pārraidāmās informācijas noslēpuma tīšu pārkāpšanu, savukārt Krimināllikuma 145. pantā - kriminālatbildība par nelikumīgām darbībām ar personas datiem, taču atbildība iestājas tikai tad, ja nodarījuma sekas ir būtisks kaitējums.

Satversmes tiesas spriedumā pamatoti norādīts:

"[..] tādēḷ, ka kriminālatbildība ir smagākais iespējamais juridiskās atbildības veids un tās sekas var būtiski ietekmēt personas dzīvi arī pēc kriminālsoda izciešanas, kriminālatbildību paredzošām normām jābūt saturiski noteiktākām nekā citu tiesību nozaru normām." [14]

N̦emot vērā visai dažādās situācijas, kad iespējams veikt ārstniecību bez pacienta piekrišanas atbilstoši Pacientu tiesību likuma 7. panta regulējumam vai Ārstniecības likuma XI nodạ̦ā ietvertajām normām, jauna Krimināllikuma norma, kurā paredzēta atbildība par ārstniecību bez informētas piekrišanas, būtu veidojama kā blanketa tiesību norma, ietverot to Krimināllikuma XIV nodạ̦ā vai grozot Krimināllikuma 138. panta dispozīciju, pārkāpumu nesaistot ar sekām. Ārstniecības personas kaitīgā darbība izpaustos gadījumā, ja tā nepildītu vai nolaidīgi pildītu savus pienākumus informētās piekrišanas sakarā, kas paredzēti Pacientu tiesību likuma un Ārstniecības likuma regulējumā.

Satversmes tiesa norādījusi, ka no Satversmes 89. pantā minētā var secināt - likumdevēja mērkis nav bijis pretstatīt Satversmē ietvertās cilvēktiesību normas starptautiskajām cilvēktiesību normām, bet gluži pretējs - panākt šo normu savstarpēju harmoniju [18]. Satversmes normās nenosaka atbildības veidu aizsargāto interešu aizskāruma gadījumā. Jāatzīmē, ka Satversmes un starptautisko tiesību normas kā minimālais standarts saturiski nav pilnīgi identisks un Satversmes normu tvērums dažkārt ir plašāks. Veicot starptautisko normu savstarpēju salïdzinājumu ar Satversmes normu, konstatēts, ka Satversmes 92. panta pirmā teikuma tvērums [1] ir plašāks par Eiropas Cilvēka tiesību un pamatbrīvību konvencijā paredzēto. Salīdzinot Eiropas Cilvēka tiesību un pamatbrīvību 
aizsardzības konvencijas 13. pantu kā vispārēju normu, kurā noteikts, ka "ikvienam, kura tiesības un brīinibas, kas noteiktas šajā konvencijā, tiek pārkāptas, ir efektīvas aizsardzības nodrošinājums valsts institūcijās, neskatoties uz to, ka pārkāpumu ir izdarijušas personas, pildot dienesta pienākumus", ar 6. pantu kā speciālo normu, secināts, ka tomēr no 6. panta pirmās daḷas teksta skaidri izriet - šì norma ir piemērojama nevis jebkura veida tiesvedībā, bet tikai civillietās un krimināllietās [24].

Atbildi uz jautājumu, kā rīkoties šādā situācijā, sniedz Satversmes tiesa, norādot:

“[..] ja, interpretējot kādu starptautisko tiesību normu, secināms, ka Satversme garantē plašāku attiecīgās pamattiesības aizsardzību, nav piel̦aujams aprobežoties vienīgi ar starptautiskajos cilvēktiesību aktos ietvertās normas piemērošanu un nepieciešams piemērot Satversmi" [16].

Šì atziṇa ir ḷoti svarīga izskatāmā jautājuma kontekstā un rada pacientam iespēju aizstāvēt savas intereses ne tikai civilprocesā vai attiecīgu seku gadījumā kriminālprocesā, bet arī administratīvajā procesā apstrīdot Veselības inspekcijas lēmumu Veselības ministrijā un pārsūdzot nelabvēlīgu lēmumu administratīvajā tiesā.

Pētot Satversmes normu, ir konstatēts:

“[..] likumdevējam, leg̣itīma mērḳa nodrošināšanai paredzot ierobežojumus, jāṇem vērā, ka tajos gadījumos, kad kā priekšnosacījums, lai vērstos tiesā, tiek noteikta ārpustiesas izskatīšanas kārtības ievērošana, tiesības uz taisnīgu tiesu skar arī tie ierobežojumi, kas tiek noteikti saistībā ar vēršanos ārpus tiesas izskatīšanas iestādē" [24].

Šo tēzi pilnībā apstiprina Pacientu tiesību likuma 17. panta otrajā daḷā ietvertais regulējums, kas paredz Veselības inspekcijas lēmumu par kompensācijas izmaksu apstrīdēt Veselības ministrijā un ministrijas lēmumu - tiesā.

Ar kādām Satversmes normām nodrošināts, ka informētā piekrišana veselības aprūpē ir līdzeklis personas brīvai izvēlei un integritātes garantijai, aplūkots raksta turpinājumā.

Satversmes 91. pantā teikts: "Visi cilvēki Latvijā ir vienlīdzīgi likuma un tiesas priekšā. Cilvēka tiesības tiek îstenotas bez jebkādas diskriminācijas." Likuma normas pirmajā teikumā ietverta tiesiskā vienlīdzība, savukārt otrajā teikumā - diskriminācijas aizliegums ar mērḳi nepię̧aut nevienlīdzīgu attieksmi, ja tā balstās uz kādu attiecīgu kritēriju. Pētnieki, analizējot likuma normas genēzi un Eiropas pamattiesību hartā ietverto regulējumu, sniedz šādu aizliegto kritēriju uzskaitỉjumu: 1) rase un ādas krāsa; 2) tautība, etniskā izcelsme; 3) valoda; 4) dzimšana un izcelsme; 5) dzimums; 6) vecums; 7) invaliditāte; 8) genētiskās īpašîbas; 9) seksuālā orientācija; 10) relig̣iskā pārliecība; 11) politiskā un cita pārliecība; 12) pasaules uzskats; 13) sociālais stāvoklis un sociālā izcelsme; 14) dienesta stāvoklis; 15) manta; 16) citi līdzīgi apstākḷi [24]. Atbilstoši Pacientu tiesību likuma 3. panta otrajai daḷai ir aizliegta atšḳirīga attieksme atkarībā no personas rases, etniskās izcelsmes, ādas krāsas, dzimuma, vecuma, invaliditātes, veselības stāvokḷa, reliǵiskās, politiskās vai citas pārliecības, nacionālās vai sociālās izcelsmes, mantiskā vai ğimenes stāvokḷa vai citiem apstākḷiem. 
Informētās piekrišanas sakarā var nākties saskarties ar situācijām, kad nepieciešams izdarìt izvēli, kas atkarīga no kritērija un konkrētiem apstākḷiem, starp aizlieguma kritērijā norādītu un personas autonomijas nodrošināšanu, piemēram, informētās piekrišanas iegūšana personas ierobežotas rīcībspējas gadījumā. Kā paredzēts Pacientu tiesību likuma 3. panta trešajā dạ̦ā, tad atšḳirīga attieksme piel̦aujama tikai gadỉjumā, ja tā ir objektīvi pamatota ar tiesisku mērķi, kura sasniegšanai izraudzìtie līdzekḷi ir samērīgi. Pamatoti tiek norādīts, ka diskriminācijas aizlieguma gadỉjumā nevienlīdzīgas attieksmes attaisnojumam ir krietni augstāks standarts, kas ir grūtāk sasniedzams nekā vienlīdzības principa gadỉjumā saskaṇā ar 91. panta pirmo teikumu [24]. Ārstniecỉbas likuma 65. pantā ir norādìts, ka psihiskie traucējumi vai psihiskā slimība nedrīkst būt par iemeslu cilvēka diskriminācijai. Informētās piekrišanas sakarā konstatējami gadījumi, kad nav bijuši tādi apstākḷi, ka jāpiemēro personai ar garīgiem veselības traucējumiem piespiedu ārstēšana atbilstoši Ārstniecības likuma 68. pantam, un arī tad, ja piemērojama piespiedu ārstēšana, iespēju robežās jāizskaidro palīdzības sniegšana šādā veidā.

Augstākā tiesa civillietā, analizējot Ārstniecības likuma 68. pantu, Satversmes 94. un 96. pantu un starptautiskos tiesïbu aktus, secinājusi:
“Arī Ārstniecības likuma 68. panta otrā daḷa paredz, ka, sniedzot psihiatrisko palīdzību bez pacienta piekrišanas šā panta pirmajā daḷā noteiktajos gadījumos, pacientam, ja tas ir iespējams, izskaidro šādas psihiatriskās palīdzības sniegšanas nepieciešamību. Tādējādi Ārstniecības likums noteica virkni pacienta tiesības veselības aprūpē, tostarp uz atbilstošu informāciju, un šĩs tiesību normas interpretējamas paplašinoši, atbilstoši starptautiskajiem cilvēktiesību standartiem, kas paredz, ka ikvienam pacientam, kas brīvprātīgi vai piespiedu kārtā ievietots psihiatriskajā iestādē, ir jādod iespēja atteikties no ārstēšanas vai citas medicīniskās iejaukšanās." [20]

Citā lietā pieteicējs saskata diskriminācijas pazīmes reliǵiskās pārliecības dẹl, ja personai tiek atteikts apmaksāt veselības pakalpojumu ārpus Latvijas, jo valstī tas ir pieejams, taču tiek isstenots ar citādu metodi, tāpēc personai ir nepien̦emams religíisku apsvērumu dēḷ.

Satversmes 93. pantā ir teikts: "Ikviena tiesības uz dzīvību aizsargā likums." Izskatāmā jautājuma kontekstā tiesības uz dzīvību jautājums var rasties, ārstniecības personai veicot vai atsakot veikt abortu klīnisku vai morālu apsvērumu dēl, kā arī sarežg̀itu operāciju gadījumā, kad pastāv dzīvības risks un personai jāizlemj, vai viṇa akceptē šādu risku, dodot informēto piekrišanu. Tomēr gadījumos, kad pacients ir piekritis ārstniecībai, nebūdams informēts par riskiem, gadījumos, ja riski ir iestājušies, būtu pamats vērtēt pacienta tiesības uz atlīdzību par viņa dzīvībai vai veselībai nodarìto kaitējumu [26]. Pacientam ir tiesības neakceptēt šādu risku un attiekties no operācijas, neatsakoties no ārstniecības kopumā. Kā uzsvērts Satversmes tiesas spriedumā, tad "valsts pienākums ir sargāt personas dzīvību ne vien no valsts pašas darbībām, bet arī no citu personu darbībām. Turklāt minētais valsts pienākums ietver ne vien uz cilvēku dzìvības aizsardzības vērstu normu izdošanu, bet arī efektīvas šo normu izpildes uzraudzības sistēmas izveidošanu." [15] Eiropas Cilvēktiesību tiesas spriedumā konstatēts, ka nepastāv normatīvais regulējums, 
lai izvērtētu personas spēju pieṇemt lēmumu par atteikšanos no ārstniecības pirms ievietošanas intensīvās terapijas nodaḷā, ar ko ir pārkāpts valsts pozitīvais pienākums nodrošināt pietiekamu veselības aprūpes noteikumu sistēmu, lai nodrošinātu pietiekamu pacienta dzīvības aizsardzību. Pacientam, kurš atsacījās no ārstniecības, netika pilnvērtīgi novērtēts psihiskais stāvoklis, un iznākumā pacients nomira [13]. Administratīvās rajona tiesas spriedumā minēts, ka vienkāršas sanācijas bronhoskopijas iespējamās komplikācijas neizraisa pacienta nāvi, taču šajā gadījumā pacients nomira tūlìt pēc procedūras pabeigšanas un eksperts nevarēja precīzi izteikties, vai šì komplikācija - sirds darbības apstāšanās - bija saistīta ar veikto fibrobronhoskopijas procedūru. Diemžēl spriedumā nav norādīts, vai šai manipulācijai pacients bija piekritis, savukārt atbilstoši Pacientu tiesību likuma 6. panta ceturtajai dal̦ai pacientam ir tiesības atteikties no ārstniecībā izmantojamās metodes, neatsakoties no ārstniecības kopumā.

Satversmes 94. pantā paredzēts, ka ikvienam ir tiesības uz brīivibu un personas neaizskaramību. Nevienam nedrīkst atṇemt vai ierobežot brīvību citādi kā tikai saskaṇā ar likumu. Pētnieki, analizējot šìs Satversmes normas, pamatoti norāda, ka subjektīvais tiesību un brīvību elements pieprasa personas piekrišanu brīvības ierobežošanai un šajā aspektā Eiropas Cilvēktiesību tiesas spriedumos pamatā skatīts saistībā ar nepilngadīgo un personu ar ierobežotu rīcībspēju tiesību ierobežošanu saistībā ar ārstniecỉbas procesu [24]. Kā redzams no Eiropas Cilvēktiesību tiesas sprieduma lietā "OG pret Latviju", tad tiesa saskatīia personas tiesības uz brīvību pārkāpumu, to nogādājot psihoneiroloǵiskajā slimnīcā pēc tiesas pieprasījuma, lai veiktu medicīnisku apsekošanu jautājuma izlemšanai par piespiedu ārstēšanas turpināšanu [12]. Augstākā tiesa spriedumā izskaidro Ārstniecības likuma kritēriju, kas kalpo par pamatu personas nogādāšanai psihiatriskajā slimnīcā, un norāda, ka "acīm redzamas briesmas sev vai apkārtējiem nevar tikt interpretētas kā traucējums vai neērtība, bet gan kā nopietns dzīvības, ḳermeṇa vai mantas apdraudējums vai pietiekošs pamats uzskatīt, ka persona šādu apdraudējumu var radit" [21].

Citā administratīvā lietā, kad Ārstniecības likuma 68. panta pirmajā dạ̣ā minētie apstākḷi netika konstatēti, taču persona tika nogādāta psihiatriskajā slimnīcā, tiesa atzina, ka noticis Satversmes 94. panta pārkāpums [23]. Arī Tiesībsargs norāda, ka "psihiatriskās palīdzības sniegšana stacionārā bez personas piekrišanas ierobežo personas tiesības uz brīvību. Latvijas Satversmes 94. pants paredz tiesības uz brīvību un personas neaizskaramibu" [38].

Savukārt, veicot pārbaudi VSIA "Slimnīca "G̣intermuiža”, Tiesībsargs konstatēja, ka "nav iespējams gūt pārliecību jautājumā, ka pacienti ir devuši savu informētu piekrišanu ne tikai stacionēšanai, bet arī konkrētam ārstēšanas plānam un medikamentozās terapijas korekcijām ārstēšanas gaitā". Atsaucoties uz Satversmes 94. pantu, kā arī Eiropas Padomes rekomendācijām par personu ar garīga rakstura traucējumiem cilvēktiesību un cieņas aizsardzību, Tiesībsargs secina, ka, "neraugoties uz to, vai persona psihiatriskā ārstniecības iestādē uzṇemta brīvprātīgi vai pret tās gribu, tai ir jābūt nodrošinātām tiesībām uz informēto piekrišanu terapijai. Savukārt, ja persona atsakās saṇemt ārstniecību, tikai 
likumā skaidri noteiktos gadījumos to var nodrošināt pret tās gribu" [38]. Turklāt personām, kuras ievietotas pret pašu gribu, informācija par veselības stāvokli un paredzamo ārstniecību sniedzama gan mutvārdos, gan rakstveidā. No teiktā secināms, ka

Tiesībsarga ieskatā Satversmes 94. pantā paredzētās tiesības uz brīīibu saistāmas arī ar informētās piekrišanas aspektu. Pamatojoties uz Eiropas Cilvēktiesību un pamatbrīvību aizsardzības konvencijas 5 . panta redakciju, brīvības ierobežošanas aspekts saistās ar personas aizturēšanu, liedzot tai tiesības brīvi pārvietoties. Līdz ar to nav šaubu, ka personām ar garīga rakstura traucējumiem pats fakts, ka tās ir nogādātas psihiatriskajā slimnīcā, saistāms ar tiesībām uz brīiỉbu, savukārt šāda pacienta piespiedu ārstēšana bez piekrišanas, autora ieskatā, saistāma ar tiesībām uz neaizskaramību. Šādā veidā varētu tikt norobežotas situācijas, kad personas tiesības uz informēto piekrišanu saistāmas ar Satversmes 94. pantu un vienlaikus Satversmes 96. pantā paredzēto privātās dzīves neaizskaramību.

Satversmes 95. pantā noteikts, ka valsts aizsargā cilvēka godu un cieṇu. Spīdzināšana, citāda cietsirdīga vai cieņu pazemojoša izturēšanās pret cilvēku ir aizliegta. Nevienu nedrīkst pakḷaut nežèlīgam vai cilvēka cieņu pazemojošam sodam. Normā uzskaitītās tiesības pieder pie absolūtām pamattiesībām, un tās nedrīkst ierobežot, pakḷaut to atzǐšanu vai izmantošanu. Šajā darbā aplūkotā jautājuma kontekstā spīdzināšana un cietsirdīga attieksme saistās ar pacientu ar garīga rakstura traucējumiem piesiešanu un izolēšanu, turklāt arī attiecībā uz ḳīmiskiem ierobežojošiem līdzekḷiem piemērojami tie paši nosacījumi - tie var tikt piemēroti vienīgi tad, kad tas ir vienīgais iespējamais veids, kā novērst draudošu kaitējumu pacientam vai apkārtējiem [28].

Kā bērnu cieṇu pazemojoša situācija tika konstatēta VSIA "Bērnu psihoneiroloǵiskā slimnīca "Ainaži"” 2018. gada sākumā, kad bērni tika fiksēti pie gultas citu bērnu klātbūtnē [38]. Ministru kabineta noteikumos Nr. 453 "Noteikumi par kārtību, kādā ierobežojami pacienti, un priekšmetiem, kurus aizliegts turēt psihiatriskajā ārstniecības iestādē" noteikti ierobežojoši lỉdzekḷi un to piemērošanas prasības personām, kuras stacionētas tikai psihiatriskajā ārstniecības iestādē bez viṇu piekrišanas, un pacientu, kuriem ārstniecība psihiatriskajā ārstniecības iestādē noteikta kā medicīniska rakstura piespiedu līdzeklis. Atbilstoši noteikumu 5. punktam ārstam ir jāizskaidro pacientam ierobežojošo lìdzekḷ piemērošanas iemesls [11]. Taču arī personai pēc veiktas operācijas vai manipulācijas vispārējā ārstniecības iestādē, kā arī vecuma iespaidā var iestāties apjukuma stāvoklis, kad tā apdraud pati sevi vai citas personas. Diemžēl esošais tiesiskais regulējums neparedz ierobežojošo līdzekḷu piemērošanu šādā gadỉjumā ar ārējo normatīvo aktu, savukārt ar slimnīcas iekšējo normatīvo aktu tas nav piel̦aujams, jo neatbilst Satversmes 116. pantam.

Satversmes 96. pantā noteikts, ka ikvienam ir tiesības uz privātās dzīves, mājokḷa un korespondences neaizskaramību. Satversmes tiesa savā spriedumā norāda, ka "tiesības uz privāto dzīvi ietver visdažādāko indivīda tiesību aspektus. Tās aizsargā indivīda fizisko un garīgo integritāti, godu un cien̦u, vārda un identitātes izmantošanu, personas datus un skar citus ar privāto dzìvi saistìtus aspektus" [16]. Satversmes tiesa atzīst, ka gods un cieņa kā aizsargājamas vērtības ir ietvertas Satversmes 95. pantā. Šajā sakarā, kā pamatoti norāda pētnieki, dažkārt Satversmes 96. pantā ietverto tiesību nošķiršana no citiem 
Satversmes pantiem, it ìpaši Satversmes 93., 94., 95., 99., 100., 105. un 110. panta, var būt problemātiska. Šādos gadījumos jāṇem vērā Satversmes 96. pantā ietverto tiesību kodols - personas patstāvība un autonomija. Ja darbība ir vērsta galvenokārt pret šīm brīvu cilvēku raksturojošām pazīmēm, tad var atzìt, ka tā aizskar tieši personas privāto dzīvi, kuras aizsardzība paredzēta Satversmes 96. pantā [24]. Atbilstoši Satversmes 116. pantam normā paredzētās tiesības var tikt ierobežotas.

Satversmes tiesa, izskatot jautājumu par tiesību ierobežojumu, paredzot kriminālatbildību par nelikumīgu narkotisko vielu lietošanu, nodarot kaitējumu savai veselïbai, spriedumā norāda, ka "tiesības uz privāto dzīvi ietver tiesības uz savu ķermeni, arī tiesības nodarìt kaitējumu savai veselībai, pat izdarìt pašnāvību" [17]. Tomēr veids, kādā persona nodara kaitējumu savai veselībai, var būt arī krimināli sodāms, tāpēc sprieduma secinājuma dạ̣ā tiesa, izvērtējot narkotisko vielu ietekmi uz sabiedrību kopumā, secina:

\footnotetext{
"Ṇemot vērā narkomānijas izplatību valstī un tās îpašo bīstamìbu, likumdevējam ir tiesības noteikt atšķirīgus ierobežojumus narkotisko un psihotropo vielu apritei. Līdz ar to izvērtējamais pamattiesību ierobežojums ir sociāli nepieciešams, jo indivīda veselībai piemīt ne vien personiska, bet arī sociāla vērtība." [17]
}

Līdz ar to joprojām Krimināllikuma $253 .{ }^{2}$ panta pirmajā daḷā ir paredzēta kriminālatbildība par narkotisko un psihotropo vielu neatḷautu lietošanu. Jāpiebilst, ka krimināltiesiski atbildība paredzēta darbību īstenotājam arī situācijās, kad persona pieprasa sevi nogalināt. Pētot šo aspektu vairāku valstu tiesību doktrīnās, ir gūta atziṇa: "tā kā dzīvībai ir fundamentāla nozīme, atteikšanās no tās ir neatgriezeniska un parasti vēlēšanās mirt rodas situācijās, kad apstākḷi neliecina par autonomu lēmumu, ir pieḷaujams aizsargāt personu no nepietiekoši pārdomāta lēmuma" [34]. Piemēram, Vācijā gadījumā, ja cietušajam ir nodarīti miesas bojājumi ar viña piekrišanu, tiek vērtēts, vai miesas bojājumu nodarī̌sanas apstākḷi nav pretrunā labiem tikumiem, par ko var iestāties kriminālatbildība [34].

Domājams, ka situācijās, kad persona atrodas brīvībā un tai salīdzinājumā ar nebrīvē esošām personām ir citāds psihiskais stāvoklis, kā arī nesalīdzināmi plašākas iespējas iegūt informāciju par nepieciešamo ārstniecību citās ārstniecības iestādēs pat ārpus valsts, tāda pacienta tiesības uz informēto piekrišanu kā privātās dzìves neaizskaramību skatāmas saistībā ar Satversmes 96. pantā paredzēto privātās dzīves neaizskaramību.

Tomēr jāatzīmē, ka gadījumā, kad pacients atsakās no ārstniecības, uz ko viṇam ir tiesības, taču tādējādi var nodarìt savai veselībai kaitējumu, ārstniecības personai atbilstoši "Pacientu tiesību likuma" 6. panta piektajai dal̦ai ir jāinformē pacients par atteikuma sekām, kā arī, ja pacients nemaina savu nodomu, viṇš jāmudina apmeklēt citu ārstu. Savukārt pacienta pienākums ir pēc ārstējošā ārsta sniegtās informācijas saṇemšanas ar savu parakstu apstiprināt lēmumu par atteikšanos no ārstniecỉbas vai par tās pārtraukšanu, vai par atteikšanos no ārstniecībā izmantojamās metodes, norādot, ka ir saṇēmis attiecīgo informāciju.

Dzimuma maiṇa ir viena no privātās autonomijas izpausmēm, tāpat kā estētiskās kirurğijas un kosmetologiskie pakalpojumi. Šie pakalpojumi ietverti Ministru kabineta noteikumu Nr. 555 "Veselības aprūpes organizēšanas un samaksas kārtība" otrajā nodaḷā medicīnas pakalpojumu klāstā, kas netiek finansēti no valsts budžeta līdzekḷiem [10]. 
Satversmes 99. pantā norādīts, ka ikvienam ir tiesības uz domas, apziṇas un religiskās pārliecības brīvību. Baznīca ir atdalīta no valsts. Latvijā ir bijuši gadījumi, kad personas religísku apsvērumu dēl nevēršas pēc palīdzības pie ārstniecības personām.

Ši iemesla dēl 2019. gadā kādas mājdzemdības beidzās ar letālu iznākumu kā mātei, tā arī bērnam. Krimināllieta par šo gadỉjumu atrodas iztiesāšanā, un generālprokurors vērsies tiesā ar prasību izbeigt Pirmās evaṇgēliskās Jēzus draudzes darbību. Šì situācija rosinājusi tiesību zinātnieci L. Mazuri pievērsties jautājumam par pārmērīgu ietekmi uz pacienta gribu kā spēkā neesošu. Viṇa norāda, ka pacienta gribu var ietekmēt ne tikai ǵimenes locekḷi: vecāki un laulātie, bet arī religiskās konfesijas pārstāvji, ārstniecības personas un aprūpētāji [35].

Citā situācijā reliǵisku apsvērumu dēl pacienta likumīgie pārstāvji neḷauj veikt nepieciešamās medicīniskās manipulācijas, kas saistītas ar asins pārliešanu, un vēlas ārstniecību veikt citā ES valstī, kur tā ìstenojama bez asins pārliešanas, bet par Latvijas valsts līdzekḷiem. Normatīvie akti šādu iespēju neparedz, tāpēc administratīvajā lietā Senāts lūdza Eiropas Savienības Tiesas prejudiciālo nolēmumu, lai noskaidrotu prasības tiesiskumu [24]. Kā norādīts tiesību doktrīnā, tad asins pārliešanas vai nepārliešanas gadījumā pastāv brīva izvēle un efektīvai personas tiesību realizācijai šāda pacienta izvēle ir respektējama [25].

Satversmes 111. pantā teikts, ka valsts aizsargā cilvēku veselību un garantē ikvienam medicīniskās palīdzības minimumu. Normā ietvertas divas tiesības - tiesības uz veselību un tiesības uz garantētu medicīniskās palīdzības minimumu. Analizējot normas pirmo dalı, var izsecināt, ka tajā "ir ietverta sabiedrības veselības aizsardzība kā kolektīva veselības aizsardzības forma un konkrēta cilvēka veselības aizsardzība kā individuāla aizsargājama vērtība" [25]. Satversmes 111. pants nav ietverts Satversmes 116. panta redakcijā, kas paredz noteiktos apstākḷos ierobežot personas tiesības. Taču tas nenozīmē, ka Satversmes 111. pantā ietvertās tiesības ir absolūtās pamattiesības, kas nav ierobežojamas: "Pamattiesības, kuru ierobežojumi expresis verbis noteikti Satversmē, taču izriet no šo tiesību būtības, ECT judikatūrā sauc par "netiešiem" jeb "normas būtībā ietvertiem ierobežojumiem" (angl. implied limitations)" [25].

Jēdziens "veselība" Ārstniecības likumā definēts šādi:

"Veselība ir fiziska, garīga un sociāla labklājība, valsts un tautas pastāvēšanas un izdzīvošanas dabiskais pamats. Veselības aprūpe ir veselības aprūpes pakalpojumu sniedzēju īstenots pasākumu komplekss, tajā skaitā telemedicīna un darbības ar zālēm un medicīniskajām ierīcēm, pacienta veselības nodrošināšanai, uzturēšanai un atjaunošanai." [8]

Pētot Satversmes 111. pantu, pamatoti atzìts, ka veselïbas tiesības ir nepieciešamas, lai varētu îstenot savas cilvēktiesības [25]. Šì tēze norāda uz veselības tiesību saistību ar citām iepriekš minētām Satversmē aizsargātām tiesībām izskatāmā jautājuma sakarā, piemēram, Satversmes 94. pantu un tajā nostiprinātajām tiesībām uz personas brīvību un personas neaizskaramību un Satversmes 96. pantu un tajā noteiktām tiesībām uz privātās dzīves neaizskaramību un pienākumu valstij veselības aprūpē nodrošināt personai individuālas tiesības brīvi pieṇem lēmumu par dažādiem veselības aprūpes pasākumiem. 


\section{Secinājumi}

1. Pacienta tiesības uz informēto piekrišanu pirms ārstniecības uzsākšanas ir pacienta individuālās tiesības un nodrošina personas autonomiju un integritāti kā neatṇemamu cilvēktiesību vērtību, kas ierobežojama vienīgi likumā paredzētos gadījumos.

2. Valsts pozitīvais pienākums atbilstoši Satversmes 89. pantam ir aizsargāt personas pamattiesības, pieñemot attiecīgas normas, taču atbildībai par šo tiesību pārkāpumu nav jābūt paredzētai vienīgi Krimināllikumā.

3. Ne katrs Satversmē garantēto tiesību aizskārums ir automātiski vērtējams kā ievērojams personas interešu aizskārums un būtiska kaitējuma elements krimināltiesību izpratnē.

4. Pacienta tiesības uz brīiību un neaizskaramību paredzētas Satversmes 94. pantā, un personas nogādāšana psihiatriskajā klīnikā bez likumā paredzēta pamata ir personas tiesību uz brīvību aizskārums, savukārt piespiedu terapija un tās maiṇa, kas veikta neatbilstoši Ārstniecības likuma XI nodaḷā ietvertajam regulējumam, ir tiesību uz neaizskaramību pārkāpums.

5. Satversmes 96. pantā paredzētās tiesības uz privātās dzìves neaizskaramību ietver tiesības uz personas autonomiju un brīvu izvēli, tāpēc ārstniecība bez informētās piekrišanas personām, kuru brīva izvēle nav ierobežota ar likumu, ir šo tiesību pārkāpums.

6. Ārstniecība bez informētās piekrišanas dažādos faktiskajos apstākḷıs var būt saistìta arī ar Satversmes 93., 95., 99. un 111. pantā paredzēto tiesību aizskārumu.

7. Atbildība par veiktu ārstniecību bez informētās piekrišanas tad, kad tā ir nepieciešama, nav paredzēta Krimināllikuma Seviškajā dạ̦ā kā nodarījums pret pacienta pamattiesībām, taču rīcība vērtējama kā ārstniecības personas pienākumu nepildīšana vai nepienācīga pildīšana.

\section{Protection of Patient Autonomy and Integrity in Law}

\section{Abstract}

Several European countries, for instance, Poland, Portugal and Liechtenstein, provide for criminal liability not only for harm to a patient in healthcare but also for treatment without the patient's consent in situations where it was necessary because of an unlawful violation of fundamental rights. The study was conducted to find out which legal norms of Chapter VIII of the Satversme (the Constitution) of the Republic of Latvia guarantee autonomy and integrity of a person, as an integral value of fundamental human rights, as well as the patient's informed consent as the patient's main means of ensuring 
these protected interests. Whether the protection of these interests is sufficiently effective or should also be provided for in a separate provision of the Criminal Law will be clarified in another study.

Keywords: Satversme (the Constitution), Constitutional Court, informed consent.

\section{Avoti un literatūra}

\section{Tiesību akti:}

1. Latvijas Republikas Satversme: Latvijas Republikas likums. 07.11.1922. Latvijas Vēstnesis. 43, 01.07.1993.

2. Konvencija par cilvēktiesību un cieņas aizsardzību biolog̣ijā un medicīnā - Konvencija par cilvēktiesībām un biomedicīnu. 04.04.1997. Latvijas Vēstnesi. 205, 30.12.2009.

3. Cilvēka tiesību un pamatbrīīību aizsardzības konvencija. 27.06.1997. Latvijas Vēstnesis. 143/144, 13.06.1997.

4. Constitution of the World Health Organization. Iegūts no: https://www.who.int/governance/ eb/who_constitution_en.pdf

5. Pacientu tiesību likums: Latvijas Republikas likums. Latvijas Vēstnesis. 205, 30.12.2009.

6. Kriminālprocesa likums: Latvijas Republikas likums. Latvijas Vēstnesis. 74, 11.05.2005.

7. Administratīvā procesa likums: Latvijas Republikas likums. Latvijas Vēstnesis. 164, 14.11.2001.

8. Ārstniecības likums: Latvijas Republikas likums. Latvijas Vēstnesis. 167/168, 01.07.1997.

9. Satversmes tiesas likums: Latvijas Republikas likums. Latvijas Vēstnesis. 103, 14.06.1996

10. Ministru kabineta 2018. gada 29. augusts noteikumi "Veselïbas aprūpes organizēšanas un samaksas kārtïba”. Latvijas Vēstnesis. 555, 05.09.2018.

11. Ministru kabineta 12.07.2016. noteikumi Nr. 453 "Noteikumi par kārtību, kādā ierobežojami pacienti, un priekšmetiem, kurus aizliegts turēt psihiatriskajāa ārstniecības iestādē”. Latvijas Vēstnesis. 134, 14.07.2016.

\section{Tiesu prakse}

12. Eiropas Cilvēktiesību tiesas 30.06.2016. spriedums lietā: OG pret Latviju. Pieteikums Nr. 69747/13.

13. Eiropas Cilvēktiesību tiesas 05.03.2014. spriedums lietā: Case of Arsaya V Ukraine. Pieteikums Nr. 55076/05.

14. Latvijas Republikas Satversmes tiesas spriedums lietā Nr. 2018-10-0103.

15. Latvijas Republikas Satversmes tiesas spriedums lietā Nr. 2012-15-0118.

16. Latvijas Republikas Satversmes tiesas spriedums lietā Nr. 2005-02-0106.

17. Latvijas Republikas Satversmes tiesas spriedums lietā Nr. 2004-10-01.

18. Latvijas Republikas Satversmes tiesas spriedums lietā Nr. 2000-03-01.

19. Latvijas Republikas Augstākās tiesas Senāta 2016. gada 29. septembra lēmums lietā Nr. SKK-190/2016.

20. Latvijas Republikas Augstākās tiesas Senāta Civillietu departamenta 2013. gada 18. oktobra spriedums lietā Nr. SKC-216/2013.

21. Latvijas Republikas Augstākās tiesas Senāta Administratīvo lietu departamenta 2009. gada 13. februāra spriedums lietā Nr. SKA-13/2009.

22. Latvijas Republikas Augstākās tiesas Senāta 2008. gada 1. septembra spriedums lietā Nr. SKK-351/2008. 
23. Latvijas Republikas Administratīvās rajona tiesas 2012. gada 30. janvāra spriedums lietā Nr. A42916109.

24. Latvijas Republikas Senāta 2019. gada 8. marta lēmums lietā SKA-43/2019. Iegūts no: http:// curia.europa.eu/juris/showPdf.jsf;jsessionid=D2207CBCAA359C41D6C7D490771B49F1?text =Hungr\%25C3\%25ADa\%252C\%2BRep\%25C3\%25BAblica\%2BCheca\%252C\%2BPolonia\&docid $=219771 \&$ pageIndex $=0 \&$ doclang $=$ LV \& mode $=$ req $\&$ dir $=\& o c c=$ first $\&$ part $=1 \&$ cid $=3045851$

\section{Literatūra}

25. Latvijas Republikas Satversmes komentāri. VIII. Cilvēka pamattiesības. Latvijas Vēstnesis. 2011.

26. Medicīnas tiesības. 2015. Autoru kolektīvs S. Slokenbergas zinātniskajā redakcijā. Tiesu namu aǵentūra, $294 \mathrm{lpp}$.

27. Pacientu tiesību likuma komentāri. Latvijas Vēstnesis. 2019.

28. Spīdzināšana, cietsirdība un pazemojums attieksmē un sodā. Latvijas Vēstnesis. 2017.

29. Apinis, P. 2019. Par Krimināllikuma 138. pantu un tā darbību pret ārstu iespējām mācìties no kḷūām. Latvijas Ārsts. 3.

30. Bankava, A., Palčeja, E. 2018. Pacientu drošība un ārstniecības personu juridiskās atbildības līkloči. Jurista Vārds. 34.

31. Boka, V. 2019. Bezkompromisa tiesiskums un drošas ārstniecības perspektīva Latvijā. Latvijas Ärsts. 2.

32. Vilka, I. 2019. Ārstniecības personu kriminālatbildība: Krimināllikuma 138. pants - vai tas ir nepieciešams. Latvijas Ārsts. 2.

33. Lācis, A. 01.08.2018. Jatrogēnijas koncepcija. Jurista Vārds. 34.

34. Leja, M. 2019. Krimināltiesību aktuālie jautājumi un to risinājumi Latvijā, Austrijā, Šveicē, Vācijā. Tiesu namu aǵentūra.

35. Mazure, L. 18.08.2020. Pārmērīgas ietekmes civiltiesiskās sekas pacienta gribas izteikumā. Jurista Vārds. 33.

36. Mincs, P. 2005. Krimināltiesību kurss .Vispārīgā daḷa. Ar U. Krastiṇa komentāru. Tiesu namu aǵentūra.

37. Palkova, K. 2019. Nepilngadīgo pacientu un ārstniecības personu tiesisko attiecību problemātika ärstniecības procesā: promocijas darbs. 195. lpp. Iegūts no: https://www.rsu.lv/sites/default/files/ dissertations/KPalkova_promocijas_darbs_rev.pdf.

38. Tiesībsarga 2019. gada 20. septembra Atzinums pārbaudes lietā 2019-25-2CD. Par cilvēktiesību nodrošināšanu VSAI “Slimnīca "Gintermuiža”". Iegūts no: http://www.tiesibsargs.lv/uploads/ content/6_6_29_1582113970.pdf.

39. Tiesībsarga 2018.gada 5.februāra Ziṇojums par bērnu tiesību pārkāpumiem VSIA “Bērnu psihoneirologiskā slimnīca "Ainaži”” Iegūts no: http://www.tiesibsargs.lv/uploads/content/6_6_29_1582113970.pdf.

40. Ziemele, I. Sk. uzrunu Satversmes tiesas mājas lapā. Iegūts no: http://www.satv.tiesa.gov.lv/. [sk. 05.10.2020.].

\section{Elektroniskie resursi}

41. Veselības inspekcijas publiskais pārskats 2019. Iegūts no: http://www.vi.gov.lv/uploads/files/ publiskais-parskats_2019.pdf.

42. Criminal Code. Iegūts no: https://www.legislationline.org/download/id/8268/file/Liechtenstein Criminal_Code_1987_am2017_en.pdf. 